\title{
Dry hot air reduces seed-borne pathogens of carrot seeds
}

\author{
L-H. Cheah, J. Townshend and D.I. Hedderley \\ The New Zealand Institute for Plant E Food Research Limited, Private Bag 11600, Palmerston North \\ 4442, New Zealand \\ Corresponding author: lianheng.cheah@plantandfood.co.nz
}

The effect of dry hot treatment of carrot seeds on seed-borne pathogens (Alternaria dauci, Fusarium solani and Xanthomonas sp.) and seed germination was investigated. Carrot seeds (no fungicide) were soaked in water for $1 \mathrm{~min}$ before being exposed to hot air $\left(70^{\circ} \mathrm{C}\right.$ or $75^{\circ} \mathrm{C}$ ) for 10,20 or 30 min and then plated on potato dextrose agar to assess pathogen growth. Treated seeds were sown in cell trays in a glasshouse to assess germination and weight of subsequent seedlings. All dry hot air treatments significantly $(\mathrm{P}<0.001)$ reduced the number of seeds bearing three pathogens compared with the control (air dried at $20^{\circ} \mathrm{C}$ ). Temperature treatment at $75^{\circ} \mathrm{C}$ for 20 and 30 min killed almost all Alternaria. This pathogen was significantly less likely to occur after $75^{\circ} \mathrm{C}$ than $70^{\circ} \mathrm{C}(\mathrm{P}=0.038)$. For Fusarium there was no significant difference between treatments. Treatment at $75^{\circ} \mathrm{C}$ reduced Xanthomonas on the seeds significantly more than $70^{\circ} \mathrm{C}(\mathrm{P}=0.031)$. Higher temperatures and longer treatment both tended to reduce germination, with the $75^{\circ} \mathrm{C}$ for 30 min treatment having the least germination. Seedling weight tended to be lower after $75^{\circ} \mathrm{C}$ than $70^{\circ} \mathrm{C}$, but length of treatment had minimal effect. It is concluded that $70^{\circ} \mathrm{C}$ for 10 or $20 \mathrm{~min}$ is the best treatment for reducing seed-borne pathogens without affecting the viability of carrot seeds.

\section{The response of potato (Solanum tuberosum L.) to the fungus Rhizoctonia solani}

\author{
S.V. Raikar, F. A. Shah, A.R. Pitman and J.M.E. Jacobs \\ The New Zealand Institute for Plant E Food Research Limited, Private Bag 4704, Christchurch 8120, \\ New Zealand \\ Corresponding author: sanjeev.raikar@plantandfood.co.nz
}

Rhizoctonia solani is a soil-borne fungal pathogen of many economically important crops. Thirteen closely related anastomosis groups (AGs) of this pathogen have been identified, each of which affects different plant species. Previous studies have suggested that $R$. solani AG3 is the main cause of disease in potato. Rhizoctonia solani infection of potato plants can result in stem canker and tubers with black scurf. Affected plants give a reduced yield, while affected tubers are considered to have reduced quality, resulting in economic loss. The current study investigated the response of different potato cultivars and lines to R. solani AG3. Thirty-two potato cultivars/lines, many actively used in the Plant \& Food Research potato breeding programme, were screened in a shadehouse pot trial. The trial was laid out in an adapted resolvable block design to ensure uniform exposure to environmental factors. Each cultivar had six replicates, four with and two without AG3 inoculum. Plants were grown to maturity and the resulting tubers were assessed for disease (black scurf). Preliminary results show that none of the lines/cultivars tested were resistant, but degrees of susceptibility varied. In this experiment, stem canker was not observed in any of the lines/ cultivars. 